\title{
Selective Crystallization of Proteins using Engineered Nanonucleants
}

\author{
Umang V. Shah, Daryl R. Williams, Jerry Y. Y. Heng*
}

Surfaces and Particle Engineering Laboratory (SPEL), Department of Chemical Engineering and Chemical Technology, Imperial College London, South Kensington Campus, London SW7 2AZ.

*Corresponding Author: jerry.heng@imperial.ac.uk

Phone: +44-(0)207-594-0784. Fax: +44-(0)207-594-5700 Web: www.imperial.ac.uk/spel 


\begin{abstract}
:
This study reports for the first time a detailed experimental investigation of protein crystallization in engineered nano-confined spaces with both controlled pore diameters and narrow pore size distributions. We propose a systematic approach for controlling the nucleation and crystallization of biological macromolecules based on a relationship between the protein radius of gyration $\left(\mathrm{R}_{\mathrm{g}}\right)$ and specific pore diameter. A series of nano-nucleants with ordered mesopores having narrow pore size distributions were prepared. The templates were tested for proteins ranging in molecular weight from $14 \mathrm{kDa}$ to $450 \mathrm{kDa}$. Well formed protein crystals were obtained on only one of the five presented nanonucleants for all protein cases tested, highlighting the unique template selectivity exhibited by these nucleants. In addition, Concanavalin A and Catalase were both crystallized at $\sim 2$ times lower supersaturation levels than previously reported by any known method. Our observations fully support theoretical studies which predict the enhanced thermodynamic stability of proteins in nanoconfined cavities, including specifically the importance of nucleant pore diameter with respect to protein radius of gyration. The nucleants described here could have major industrial applications for downstream separation and purification of biopharmaceuticals, as well as improved opportunities for the crystallization of complex proteins for structural determination.
\end{abstract}

Key Words: Heterogeneous crystallization, Protein, Mesoporous Templates, Porosity, Nucleation, Confinement 


\section{Introduction:}

A key element for the successful structure determination of proteins depends on obtaining protein single crystals of good diffraction quality ${ }^{1,2}$. Even after 150 years of extensive research, obtaining diffraction quality macromolecular crystals remains more art than science, and is generally accepted to be the major bottleneck in the progress of molecular biology and its therapeutic applications ${ }^{3}$. Recent statistics obtained from the Protein Expression Purification and Crystallization Database (PepcDB) are concerning. They report only an overall $\sim 2 \%$ success rate from protein cloning to successful structure determination (i.e. out of more than 180,000 proteins cloned, $\sim 4500$ structures have been solved).

Another reason for an increasing interest in protein crystallization is as an alternate to chromatographic separation methods, which currently forms the backbone of the biopharmaceuticals manufacturing process ${ }^{4}$. The main reason for this interest are close aligned to the fact that $\sim 80 \%$ of final biopharmaceutical production costs are currently associated with downstream processing, which means specifically chromatography related costs. Our societal need to produce new biopharmaceuticals which are both efficacious and affordable necessitates a need to evaluate other lower cost protein purification and separation processes such as crystallization.

Nucleation is the first step of any crystallization process. Crystal formation from solution is a first order phase transition, which starts with nucleation. Nucleation is considered pivotal not only in inducing crystallization but also in controlling crystal quality ${ }^{5}$. Once the nucleus is formed, it optimally grows in metastable conditions, which are energetically unfavorable for forming new stable nuclei. Nucleation under metastable conditions can be obtained and controlled by providing energetically favorable sites (seeds or other surfaces), which can lower the energy barrier required to form nuclei and obtain controlled heterogeneous crystallization ${ }^{6}$. The search for suitable materials which can induce and control nucleation of a wide variety of proteins, has been ongoing for over 30 years and a variety of approaches have been used to promote and control nucleation to obtain diffraction quality protein crystals $^{7-15}$. These approaches include the effects of epitaxy, surface morphology, disordered porosity, 
surface roughness and surface chemistry, as well as the use of various crystalline and amorphous miscellaneous material ${ }^{7,10,11,13,16-20}$. This work has offered little in terms of systematic methodological understanding, and most studies have been highly empirical in their approach. Nevertheless these materials have exhibited some limited successes for selected systems, though most of these studies have offered a very limited theoretical insight into the reasons for success, or failure, of the nucleants deployed.

Numerous porous solid state materials (porous silicon, bioactive glasses, mesoporous gold and porous glasses) with broad pore size distributions, as well as disordered pore shapes and structures, have been reported to be successful substrates for crystallizing different proteins. These materials have been promoted as potential candidates for use as universal nucleants. The wide range of pore sizes offered by these materials are argued to suit a wide range of proteins due to the different critical nucleus sizes exhibited by different proteins ${ }^{2,21}$. Indeed it is argued that the lack of selectivity exhibited by these materials is one of their primary benefits. It has been previously reported that surfaces with narrow pore size distributions and structured pore arrangement failed to influence nucleation and crystallization $^{16,22,23}$. This could be due to inappropriate pore size range or chemistry of the substrate used. Very recently proteins to be crystallized were used as templates to imprint polymers, and these molecularly imprinted polymers were then used to crystallize a range of proteins. However, this work though interesting, does not provide a robust method which can be used to crystallize proteins reliably for a wide range of molecular weights, as during imprinting it is very difficult to control the aggregation and unfolding of the proteins ${ }^{24}$.

A number of researchers using simulations and models have theoretically predicted the solution behavior of selected proteins in nano-confined spaces. Wu et al. have reported that proteins constrained within nano-size cylinders exhibited much higher rates of protein folding and improved thermodynamic stability as reflected in their folding temperatures ${ }^{25}$. This enhanced folding rate is driven by the geometrical restriction in the conformation space for the protein molecule, with protein stability 
increasing as the pore diameter decreases and approaches twice $\mathrm{R}_{\mathrm{g}}$ for the proteins in question. Zhang and Cheung have modeled protein confinement in spherical and ellipsoidal nano-spaces ${ }^{26}$. They also reported enhanced levels of protein folding and protein thermodynamic stability, with folding temperatures increased by $70 \mathrm{~K}$ for pores sizes equal to twice $\mathrm{R}_{\mathrm{g}}$ compared to the bulk conditions. Their analysis assumed repulsive interactions between the pore wall and the protein. Mittal and Best have also modeled protein confinement and have produced a number of scaling laws for protein stability versus confinement dimensions ${ }^{27}$. Again optimal conditions for stability and folding occur as the confinement dimensions approach twice $\mathrm{R}_{\mathrm{g}}$. Whilst the relationship between protein confinement in nano-cavities and protein nucleation phenomena is complex and not currently fully understood, it is a reasonable assumption that any process which facilitates the formation of the thermodynamically most stable state protein solution conformation which could be expected to facilitate the overall process of protein nucleation.

No previous experimental study has systematically investigated the influence of surface templates with narrow pore size distributions for controlling nucleation and crystallization of biological macromolecules. The current study seeks to understand the heterogeneous crystallization of specific protein molecules on surfaces with controlled pore diameters, and in doing so establish a correlation between pore diameter and protein solution properties. Such an understanding would allow the development of new systematic methods for crystallization of specific biological macromolecules.

\section{Methods:}

\section{Synthesis and Characterization of Mesoporous Glasses:}

In order to engineer pores in the pore diameter size range 3-4nm, templates were synthesized using solgel based methods reported in the literature ${ }^{28}$. Different volumetric ratios of DI water and the silica precursor (tetraethyl ortho-silicate (TEOS)) as well as catalyst and TEOS were used to prepare different materials. To synthesize the material with larger pore diameters with an ordered structure, two different 
sacrificial templates (tri-block copolymer surfactants Pluronic F127 \& Pluronic P123) were used. The

synthesis conditions used here were based on the recipe reported earlier in the literature ${ }^{29,30}$. Details of synthesis are described in Supporting Information.

The material synthesized was characterized by employing $\mathrm{N}_{2}$ sorption based Brunauer-EmmettTeller (BET) and Barrett-Joyner-Halenda (BJH)/ Kelvin equations for the specific surface area and pore size distribution respectively ${ }^{31,32}$. Transmission electron microscope was also used to qualitatively observe the pore diameter and the pore structure arrangement. Details of characterization are described in Supporting Information.

\section{Crystallization of Proteins:}

The hanging drop vapor diffusion method was used for the crystallization of proteins on the mesoporous templates. A mesoporous glass template particle was added to the droplet. Seven different model proteins were used for crystallization experiments. The metastable crystallization conditions for each of the proteins were obtained from literature and further optimized experimentally ${ }^{16}$. Details of these optimized crystallization conditions used are listed in Table 4. Protein crystallization details are further described in Supporting Information

The qualitative observation of crystallization process was carried out using the Olympus BX51M reflective microscope (Olympus UK Ltd., UK), which is equipped with the Olympus DP70 digital camera (Olympus UK Ltd., UK) for digital imaging. Single crystal X-ray diffraction data collection the protein crystals were obtained using a Rigaku Single Crystal X-ray Diffractometer. Details of characterization are described in Supporting Information. 


\section{Results:}

\section{Preparation of Mesoporous Glass Surfaces:}

Mesoporous glasses with pore sizes $<4 \mathrm{~nm}$ were synthesized using sol-gel based methods. To synthesize materials with higher pore diameters and ordered structures, two different sacrificial templates processes were used with tri-block copolymer surfactants (Pluronic F127 \& Pluronic P123). Different acid based catalysts were also deployed to optimize surface porosity. Mesoporous template surfaces with five different pore diameter ranges were prepared namely, Type-I, II, III, IV, V which have pore diameters of $3-4 \mathrm{~nm}, 6-8 \mathrm{~nm}, 10-12 \mathrm{~nm}, 13-15 \mathrm{~nm}$ and $17-21 \mathrm{~nm}$ respectively. Table 1 presents the physical properties of the templates and Figure 1 shows the pore size distributions of the same templates based on Nitrogen isotherms (Barrett-Joyner-Halenda/ Kelvin equation based method ${ }^{32}$ ). Transmission Electron Micrographs of the corresponding materials are shown in Figure 2. It is evident from the results shown here that the mesoporous templates used in this study have narrow pore size distributions and exhibit highly ordered pore structures.

\section{Effect of Nucleant Surface Porosity on Protein Crystallization:}

The crystallization of seven different proteins ranging in molecular weight from $14 \mathrm{kDa}$ to $450 \mathrm{kDa}$ were carried out using mesoporous glass surfaces with five different pore size ranges i.e. $3-4 \mathrm{~nm}$, 6-8nm, $10-12 \mathrm{~nm}, 13-15 \mathrm{~nm}, 17-21 \mathrm{~nm}$ and a clean non-porous bare glass slide, which was used as the control surface. Figure 3 presents the qualitative results to highlight the effect of specific nucleant porosity on crystallization of selective protein molecule, whereas Table 2 shows the results of the experiments performed under reported metastable conditions. Details of crystallization experimental observations are reported below.

Lysozyme: Crystals of lysozyme was observed within 12-24 hours on surfaces with pore diameter 34nm. The optical micrographs of crystals obtained on this surface are shown in Figure 3(a). At similar time no crystals were observed on any other surfaces. All porous and control non-porous surface 
resulted in crystals of lysozyme within 7 days of experimental observation.

Thaumatin: First crystals of thaumatin were observed within 18-24 hours only on the surface with pore diameter 3-4nm (Figure 3(b)). At this same time no crystal were observed on any other surfaces. All porous surfaces yielded some crystals within 15 days. No crystals were observed on the non-porous control surface.

Trypsin: Crystals formed within 48-72 hours on the surfaces with a pore diameter 3-4nm. No crystals on surfaces with any other pore diameter or control surfaces were observed within 15 days. Optical micrographs of the crystals obtained on surfaces with pore diameter 3-4nm are shown in Figure 3(c). Human Serum Albumin (HSA): Crystals formed within 36-48 hours on the surface with 6-8nm pore diameters. Crystals were observed after 5 days on the surface with 3-4nm pores. All other surfaces (porous and non-porous control) exhibited no crystal for the full 15 days. HSA has not been previously crystallized on any other porous surfaces.

Concanavalin A-Type IV: Diffraction quality crystals of concanavalin A were only obtained on the nucleants with pore diameter $10-12 \mathrm{~nm}$ within $24-36$ hours. The results of the same are reported in Figure 3(d). Uncontrolled showers of crystals were observed on the surface with pore diameter 3-4nm after 48 hours. These crystals were found to be of poor diffraction quality. No crystals on surfaces with any other pore diameter or control surfaces were observed within 15 days. Concanavalin A is a tetramer and all other previous attempts to crystallize it on porous nucleants with broad pore size distributions have failed to yield crystals ${ }^{16}$.

Catalase: Crystals were only observed on the surface having pore diameter 10-12nm within 48-72 hours (Figure 3(e)). No crystals on surfaces with any other pore diameter or control surfaces were observed within 15 days. Catalase, which is a tetramer having molecular weight $\sim 10 \times$ higher than thaumatin is relatively large molecule, which molecularly imprinted polymers fail to crystallize ${ }^{24}$.

Ferritin: Ferritin crystals were observed on the surfaces with pore diameter 17-21nm within 48-60 hours (Figure 3(f)). No crystals were observed on any other surfaces at the similar time scale. Showers 
of very small crystals were observed on surfaces with pore diameter $13-15 \mathrm{~nm}$ within 72 hours. No other surfaces resulted in crystals within 15 days of experimental observation. Ferritin is an iron storing protein, having 24 subunits and approximately double the molecular weight compared to catalase, has not been previously crystallized using any other porous hetronuclei.

Proteins with lower molecular weights in the range of $14-24 \mathrm{kDa}$ were successfully crystallized on the nucleant surfaces with the pore diameter 3-4nm, whereas the two proteins having higher molecular weights, in the range of $106-232 \mathrm{kDa}$, were only crystallized on surface with pore diameter $10-12 \mathrm{~nm}$. Human serum albumin, which has a molecular weight $67 \mathrm{kDa}$ crystallized on the surface with intermediate pore diameter of 6-8nm, whereas no crystals were observed on the bare glass slide or all other templates with any other porosity for all the proteins at similar timescale. Ferritin (450kDa), which is having approximately double molecular weight compared to catalase, was observed to be crystallized only on the surfaces having pore diameter $17-21 \mathrm{~nm}$. Furthermore, the induction times measured for first obtaining crystals on these surfaces are $10-75 \%$ shorter compared to those reported in the published literature for any other porous substrates or heterogeneous nucleants under comparable crystallization conditions $^{7,10,11}$.

A key observation of the current study is the preferential crystallization of proteins on specifically engineered surfaces with controlled pore diameter and narrow pore size distribution. The extent of this preferential behavior varied from being fully selective in that some proteins only crystallized on one template, independent of the time frame observed. In other cases crystallization occurred on one template initially, with other templates seeing crystallization at much later timeframes. Such substrate selectivity in the heterogeneous crystallization of proteins has not been previously reported.

Heterogeneous nucleation does not crucially affect the nucleation process under higher supersaturation conditions $^{33}$. To isolate the effects of specific pore diameter, crystallization was performed under lower protein concentrations than those reported as metastable conditions, whilst maintaining all other crystallization conditions. Crystallization was observed to occur at significantly lower protein 
concentrations than reported for any other porous hetero-nuclei ${ }^{2,16,24}$. Details of the protein concentration for crystallization are listed in Table 3.

Though previous work has highlighted the potential role of mesoporous materials in protein nucleation, the results obtained have been variable. For example, previous efforts to crystallize proteins on zeolites and other related materials based ordered micro/mesoporous substrates with narrow pore size distribution have failed ${ }^{16,24}$. Similar studies with disordered mesoporous materials were more successful but could not crystallize Concanavalin A which was crystallized here successfully using a specifically engineered mesoporous substrate; the Type-IV nucleant ${ }^{16}$.

The metastable conditions for heterogeneous crystallization of proteins reported in the literature were used as the starting point in the current work ${ }^{2,16,34}$. To isolate the influence of the surface porosity on controlling nucleation, several experimental controls were performed : (i) droplets of the same protein trial were prepared from the same and different batches of protein and precipitant solutions, (ii) mesoporous surfaces used were from the same and different batches of synthesis experiments, surfaces were cleaned and degassed before use, (iii) before inverting the slide, all the droplets are kept in open air for approximately similar time. (iv) All results presented here were repeated $(n=5)$ to confirm data reproducibility and reliability.

\section{Discussion:}

It is postulated that protein molecules from the dilute solution enter the nano-pores via a combination of diffusion and capillary action. The localized immobilization of the molecules within the optimum pore will effectively increase local supersaturation and thus drive forward the process of nucleus formation $^{21,35}$. Although this mechanism represents a macroscopic explanation, the assumptions in the development of the classical framework oversimplify the process and limit its applicability in interpreting experimental findings ${ }^{36}$.

A more comprehensive explanation of the macromolecular crystallization can be provided by the two 
step nucleation mechanism. Here the formation of crystals from dilute solution follows the path in which an initial formation of a dense liquid phase occurs from the dilute liquid (difference in concentration) and from this dense liquid phase, due to increase in local supersaturation, the critical nucleus forms within the dense phase (structural change) ${ }^{37-39}$. The nucleants used in the current work are silica based materials, which exhibit weak attractive interactions towards the proteins under investigation, within the crystallization conditions used here. Due to these attractive interactions, the formation of a highly dense liquid phase, which is rich in solute, should be facilitated by the hydrophilic surface chemistry. The concentration difference can be a factor which distinguishes between the dilute solution and highly dense phase. Formation of such a high density phase has been observed and characterized using light scattering based techniques ${ }^{40,41}$.

At such higher supersaturation, surface porosity plays a significant role in not only inducing nucleation, but also in the stabilization of the nucleus formed. Considering the Gibbs Thompson expression, the critical nucleus size is an inverse function of supersaturation, hence the critical nucleus size required to induce nucleation at such high supersaturation is postulated to be minimum ${ }^{42}$. The macromolecules in the highly dense phase near to the surface enter the pores under atmospheric pressure via capillary rise. Once the protein molecules have entered in the pores, the local immobilization of the macromolecule within the pore is thought to reduce free energy barrier required for formation of nucleus. Proteins and other biological macromolecules, have flexible domains and the shape of molecules are also not spherical, hence the diameter of gyration is thought to provide a more realistic picture as compared to the critical nucleus size, which is also very difficult to determine at supersaturation for nucleation $^{43}$. When the pore diameter is slightly larger in size than the diameter of gyration of macromolecule, induction and stabilization of the nucleus occurs. The diameter of gyration $\left(D_{G}=2 \times R_{g}\right)$ reported for the proteins crystallized in the present study (under similar conditions agree) with this mechanism proposed ${ }^{44-48}$. The diameter of gyration of the protein and the template average pore diameters are shown as function of protein molecular weight in Figure 4. 
Another rationalization of our nucleation observations can be described based on the entropic implications of protein nano-confinement. A nanoscale mechanism of nucleation is supported by recent theoretical studies which have highlighted unique protein solution behavior when confined or restricted to nanometer dimensional spaces. These studies provide for the first time a theoretical framework which may help explain why mesoporous solids with controlled pore diameter, as reported here, are especially successful in achieving solution thermodynamic stability, which may lead to energetically favorable environment for the protein folding and nucleation. Wu et al. have reported that proteins constrained within nano-size cylinders exhibited much higher rates of protein folding and improved thermodynamic stability as reflected in the folding temperatures ${ }^{25}$. These enhanced folding rates are driven by the geometrical restrictions in the conformation space (i.e. entropic) for the protein molecule, with protein stability increasing as the pore diameter decreased and approached twice the $\mathrm{R}_{\mathrm{g}}$ for the protein in question. They also concluded that pore height and diameter also play a role in determining folding rates, though the effects of pore height have not been addressed in the current study. This work also acknowledges the existence of nanometer channels in some natural systems such as ribosome tunnels and chaperonin protein cavities, and that these natural mesoporous structures could well have a key role in facilitating protein folding. Zhang and Cheung have modeled protein confinement in spherical and ellipsoidal nano-spaces ${ }^{26}$. For confinements spaces $>5 \times R_{g}$, protein stability was comparable to that of the bulk solution space. Enhanced levels of protein folding and protein thermodynamic stability, with folding temperatures increased by $70 \mathrm{~K}$, were reported for pores sizes equal to $2 \mathrm{x} \mathrm{R}_{\mathrm{g}}$ compared to the bulk conditions, assuming repulsive interactions between the pore wall and the protein. They argue that an optimally engineered confinement will lower the energy barrier of transitions states in the free energy reaction co-ordinate space. Mittal and Best have also modeled protein confinement and have produced a number of scaling laws for protein stability versus confining dimensions ${ }^{27}$. Again best conditions for stability and folding occur as confinement dimensions approaches twice the protein's $\mathrm{R}_{\mathrm{g}}$. The relationship between protein confinement in nano-cavities and protein nucleation phenomena is a new 
topic which is not yet fully understood. According to Zhang and Cheung these enhancements can be ascribed to the reduction in the activation energy for the relevant transition state. These authors argue that as the pore shape and size approaches that of the size and shape of the proteins transition state, then the restriction in conformations possible facilitates thermodynamically the most stable and favorable state for nucleation ${ }^{26}$.

From the data experimentally reported here, it is clear that number of protein molecules within a critical nucleus for the experimental conditions reported here must be a minimum based on close relationship between pore diameter and $\mathrm{R}_{\mathrm{g}}$ for all of the proteins reported here. Such small critical nuclei are especially interesting as every molecule can be the precursor for the crystalline phase, and that their subsequent growth into dimers, and ultimately a crystal, occurs with a free energy gain ${ }^{38,49}$. Indeed the energy barrier for the creation of such a crystalline phase is available within the inherent thermal energy possessed by the molecules. From Table 3 it can be seen that a number of the species crystallized in the current study have been crystallized at lower concentrations than previously reported. Such an observation is consistent with the existence of lower than normal energy barriers to nuclei formation which could be due to a minimum critical nucleus size being achieved using the engineered mesoporous substrates used here.

\section{Conclusion:}

In summary, contrary to all previous reports, it is demonstrated here for the first time that surfaces with specific pore diameters and narrow pore size distributions, are highly effective at inducing the crystallization of specific protein molecules. Crystallization of proteins was found to be strongly dependent on pore size, with a direct correlation with protein radius of gyration. This selectivity in crystallization is argued to be direct consequence of local immobilization of protein molecules, which varies in radius of gyration, within nano-confinement and ultimately formation and stabilization of nucleus within the pores of specific size. Additionally, this is the only known experimental study to 
report the successful crystallization of Concanavalin A, HSA and Ferritin on porous substrates. The success can be attributed to a specific surface pore size suitable to induce nucleation. Furthermore, the crystals are obtained at lower protein concentration and induction time as compared to one reported in the literature using the surfaces with specific porosity. 


\section{Acknowledgement:}

We thank Dr. Daniela Tsekova, Mr. Mark Allenby and Ms. Shanshan Huang for experimental help with ferritin, human serum albumin and Lysozyme respectively, Dr. Jeremy Moore, for helping with collecting and analyzing single crystal X-ray diffraction data and indexing using CCP4 software packages, Prof. Paul F. Luckham for the motivating discussions and critical comments. U V Shah acknowledges the Education Department, Government of Gujarat, Gandhinagar, India for granting a study secondment to Imperial College London. 


\section{References:}

(1) Chayen, N. E. Trends Biotechnol. 2002, 20, 98-98.

(2) Chayen, N. E.; Saridakis, E.; Sear, R. P. Proc. Natl. Acad. Sci. U.S.A. 2006, 103, 597-

601.

(3) McPherson, A. Methods 2004, 34, 254-265.

(4) Przybycien, T. M.; Pujar, N. S.; Steele, L. M. Curr. Opin. Biotechnol. 2004, 15, 469-478.

(5) De Yoreo, J. J.; Vekilov, P. G. Rev. Mineral. Geochem. 2003, 54, 57-93.

(6) Mullin, J. W. Crystallization; Elsevier Butterworth-Heinemann: Oxford, 2001.

(7) Tosi, G.; Fermani, S.; Falini, G.; Gallardo, J. A. G.; Ruiz, J. M. G. Acta Crystallogr., Sect. D: Biol. Crystallogr. 2008, 64, 1054-1061.

(8) Saridakis, E.; Chayen, N. E. Trends Biotechnol. 2009, 27, 99-106.

(9) Fermani, S.; Falini, G.; Minnucci, M.; Ripamonti, A. J. Cryst. Growth 2001, 224, 327334.

(10) Falini, G.; Fermani, S.; Conforti, G.; Ripamonti, A. Acta Crystallogr., Sect. D: Biol. Crystallogr. 2002, 58, 1649-1652.

(11) Takehara, M.; Ino, K.; Takakusagi, Y.; Oshikane, H.; Nureki, O.; Ebina, T.; Mizukami, F.; Sakaguchi, K. Anal. Biochem. 2008, 373, 322-329.

(12) Georgieva, D. G.; Kuil, M. E.; Oosterkamp, T. H.; Zandbergen, H. W.; Abrahams, J. P. Acta Crystallogr., Sect. D: Biol. Crystallogr. 2007, 63, 564-570.

(13) McPherson, A.; Shlichta, P. Science 1988, 239, 385-387.

(14) Delmas, T.; Roberts, M. M.; Heng, J. J. Adhes. Sci. Technol. 2011, 25, 357-366.

(15) Thakur, A. S.; Robin, G.; Guncar, G.; Saunders, N. F. W.; Newman, J.; Martin, J. L.; Kobe, B. PLoS ONE 2007, 2, e1091.

(16) Chayen, N. E.; Saridakis, E.; El-Bahar, R.; Nemirovsky, Y. J. Mol. Biol. 2001, 312, 591595.

(17) Stolyarova, S.; Saridakis, E.; Chayen, N. E.; Nemirovsky, Y. Biophys. J. 2006, 91, 38573863. 12445.

(18) Curcio, E.; Fontananova, E.; Di Profio, G.; Drioli, E. J. Phys. Chem. B 2006, 110, 12438-

(19) Curcio, E.; Curcio, V.; Profio, G. D.; Fontananova, E.; Drioli, E. J. Phys. Chem. B 2010, $114,13650-13655$.

(20) Pham, T.; Lai, D.; Ji, D.; Tuntiwechapikul, W.; Friedman, J. M.; Randall Lee, T. Colloids Surf., B 2004, 34, 191-196.

(21) Page, A. J.; Sear, R. P. Phys. Rev. Lett. 2006, 97, 065701.

(22) Rong, L.; Komatsu, H.; Yoshizaki, I.; Kadowaki, A.; Yoda, S. J. Synchrotron Radiat. 2004, 11, 27-29.

(23) Kertis, F.; Snyder, J.; Govada, L.; Khurshid, S.; Chayen, N.; Erlebacher, J. JOM 2010, $62,50-56$.

(24) Saridakis, E.; Khurshid, S.; Govada, L.; Phan, Q.; Hawkins, D.; Crichlow, G. V.; Lolis, E.; Reddy, S. M.; Chayen, N. E. Proc. Natl. Acad. Sci. U.S.A. 2011, 108, 11081-11086.

(25) Lu, D.; Liu, Z.; Wu, J. Biophys. J. 2006, 90, 3224-3238.

(26) Zhang, S.-Q.; Cheung, M. S. Nano Lett. 2007, 7, 3438-3442.

(27) Mittal, J.; Best, R. B. Proc. Natl. Acad. Sci. U.S.A. 2008, 105, 20233-20238.

(28) Ahmad, M.; Jones, J. R.; Hench, L. L. Biomed. Mater. 2007, 2, 6-10.

(29) Zhao, D.; Feng, J.; Huo, Q.; Melosh, N.; Fredrickson, G. H.; Chmelka, B. F.; Stucky, G. D. Science 1998, 279, 548-552.

(30) Zhao, D.; Huo, Q.; Feng, J.; Chmelka, B. F.; Stucky, G. D. J. Am. Chem. Soc. 1998, 120, 6024-6036.

(31) Brunauer, S.; Emmett, P. H.; Teller, E. J. Am. Chem. Soc. 1938, 60, 309-319.

(32) Barrett, E. P.; Joyner, L. G.; Halenda, P. P. J. Am. Chem. Soc. 1951, 73, 373-380. 
(33) Tosi, G.; Fermani, S.; Falini, G.; Gavira, J. A.; Garcia Ruiz, J. M. Cryst. Growth Des. 2011, $11,1542-1548$.

(34) Asanithi, P.; Saridakis, E.; Govada, L.; Jurewicz, I.; Brunner, E. W.; Ponnusamy, R.; Cleaver, J. A. S.; Dalton, A. B.; Chayen, N. E.; Sear, R. P. ACS Appl. Mater. Interfaces 2009, 1, 12031210 .

(35) van Meel, J. A.; Sear, R. P.; Frenkel, D. Phys. Rev. Lett. 2010, 105, 205501.

(36) Erdemir, D.; Lee, A. Y.; Myerson, A. S. Acc. Chem. Res. 2009, 42, 621-629.

(37) Vekilov, P. G. Nanoscale 2010, 2, 2346-2357.

(38) Vekilov, P. G. Cryst. Growth Des. 2010, 10, 5007-5019.

(39) Wolde, P. R. t.; Frenkel, D. Science 1997, 277, 1975-1978.

(40) Streets, A. M.; Quake, S. R. Phys. Rev. Lett. 2010, 104, 178102.

(41) Malkin, A.; McPherson, A. Acta Crystallogr., Sect. D: Biol. Crystallogr. 1994, 50, $385-$ 395.

(42) Gibbs, J. W. Collected Works, Thermodynamics; Yale University Press: New Haven, 1948; Vol. 1.

(43) Yau, S. T.; Vekilov, P. G. J. Am. Chem. Soc. 2001, 123, 1080-1089.

(44) Kuznetsov, Y. G.; Konnert, J.; Malkin, A. J.; McPherson, A. Surf. Sci. 1999, 440, 69-80.

(45) Caracciolo, G.; Amiconi, G.; Bencivenni, L.; Boumis, G.; Caminiti, R.; Finocchiaro, E.; Maras, B.; Paolinelli, C.; Congiu Castellano, A. Eur. Biophys. J. 2001, 30, 163-170.

(46) Olivieril, J. R.; Craievich, A. F. Eur. Biophys. J. 1995, 24, 77-84.

(47) Pallarola, D.; Queralto, N.; Knoll, W.; Ceolín, M.; Azzaroni, O.; Battaglini, F. Langmuir 2010, 26, 13684-13696.

(48) Malmon, A. G. Biochim. Biophys. Acta 1957, 26, 233-240.

(49) Galkin, O.; Vekilov, P. G. Proc. Natl. Acad. Sci. U.S.A. 2000, 97, 6277-6281. 


\section{Figures:}

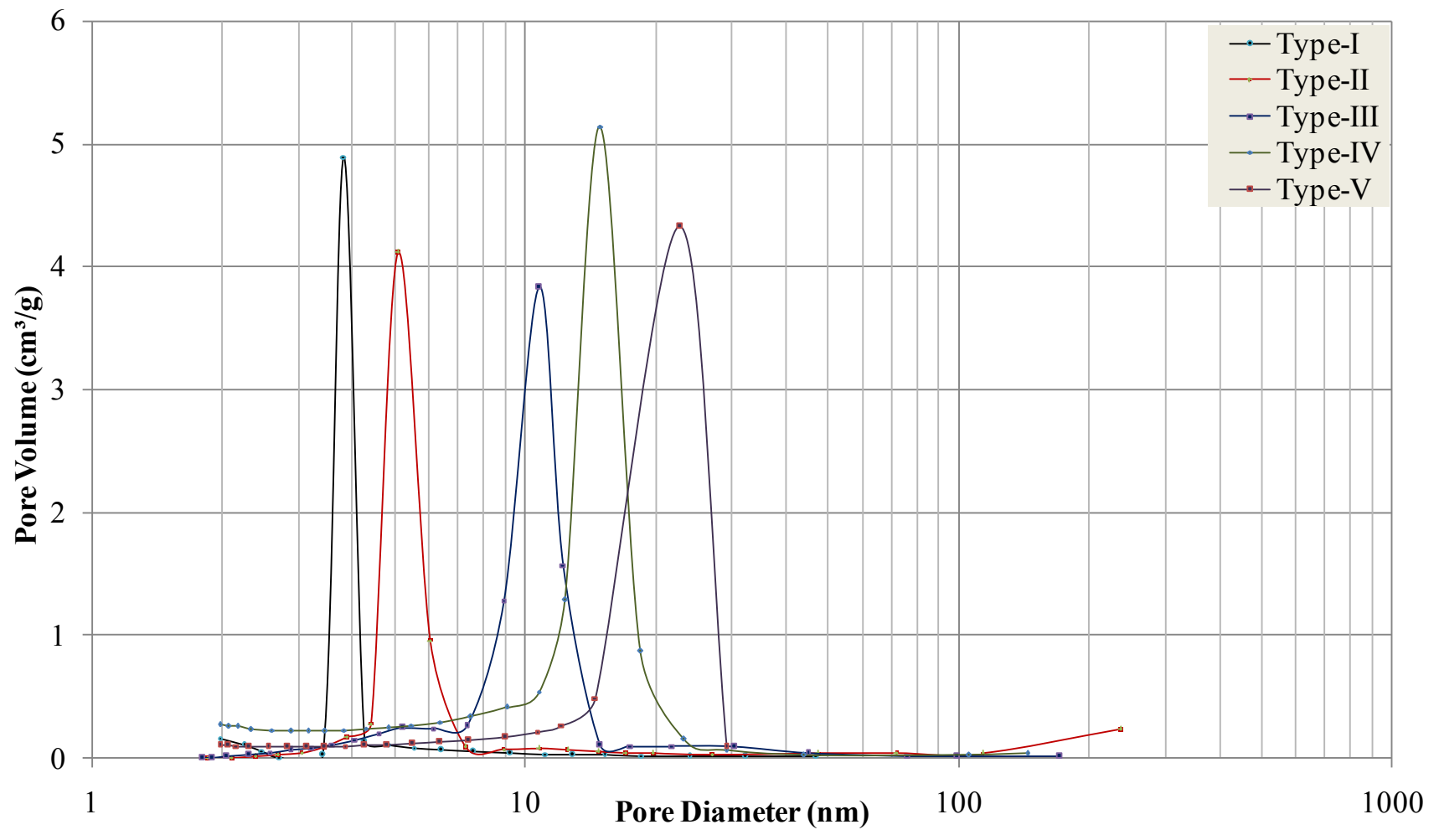

Figure 1 Pore size distribution of monoliths produced with different sacrificial templates. 

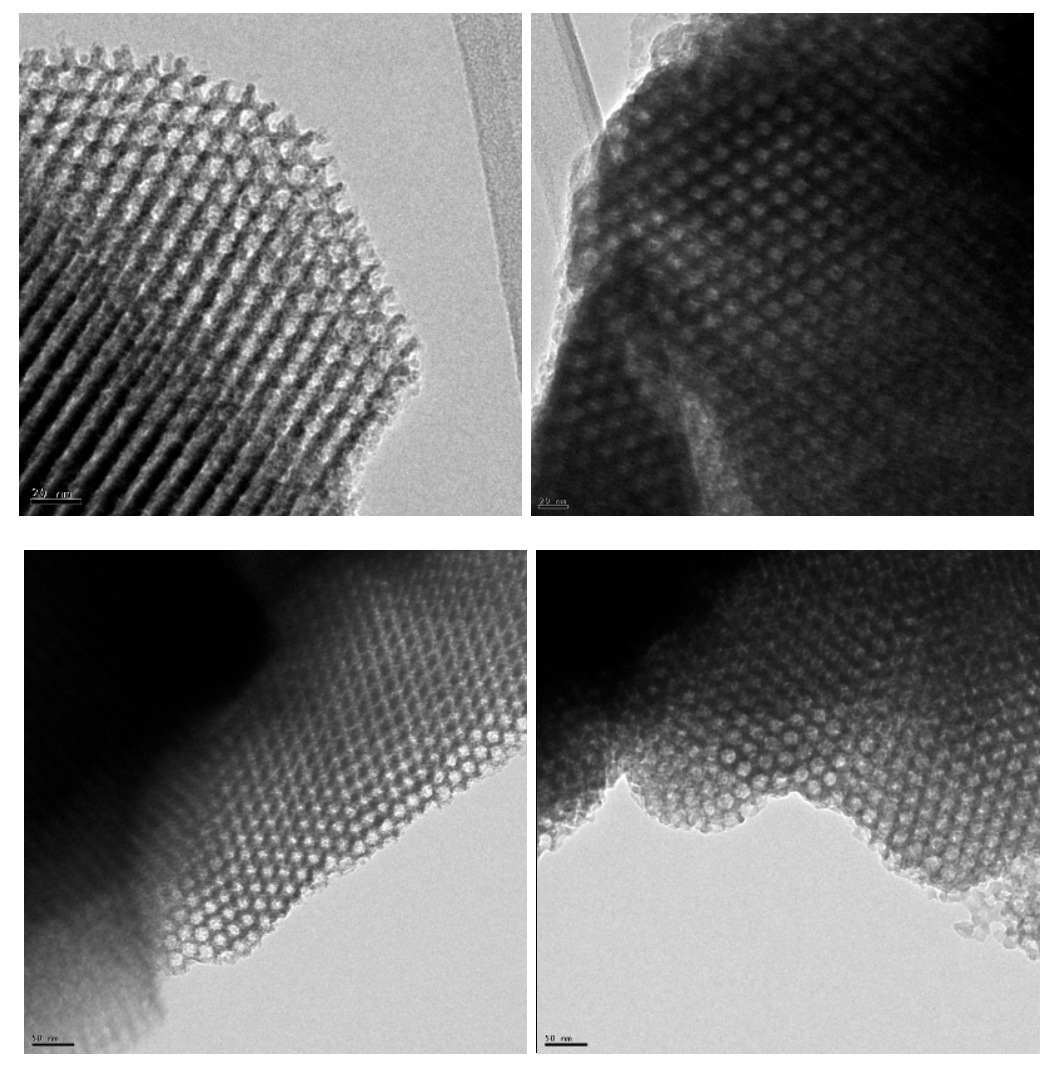

Figure 2 Transmission Electron Micrographs of (a) Type - II (scale bar 20nm) (b) Type - III (scale bar 20nm) (c) Type - IV (scale bar 50nm) (d) Type - V (scale bar 50nm) mesoporous templates. 

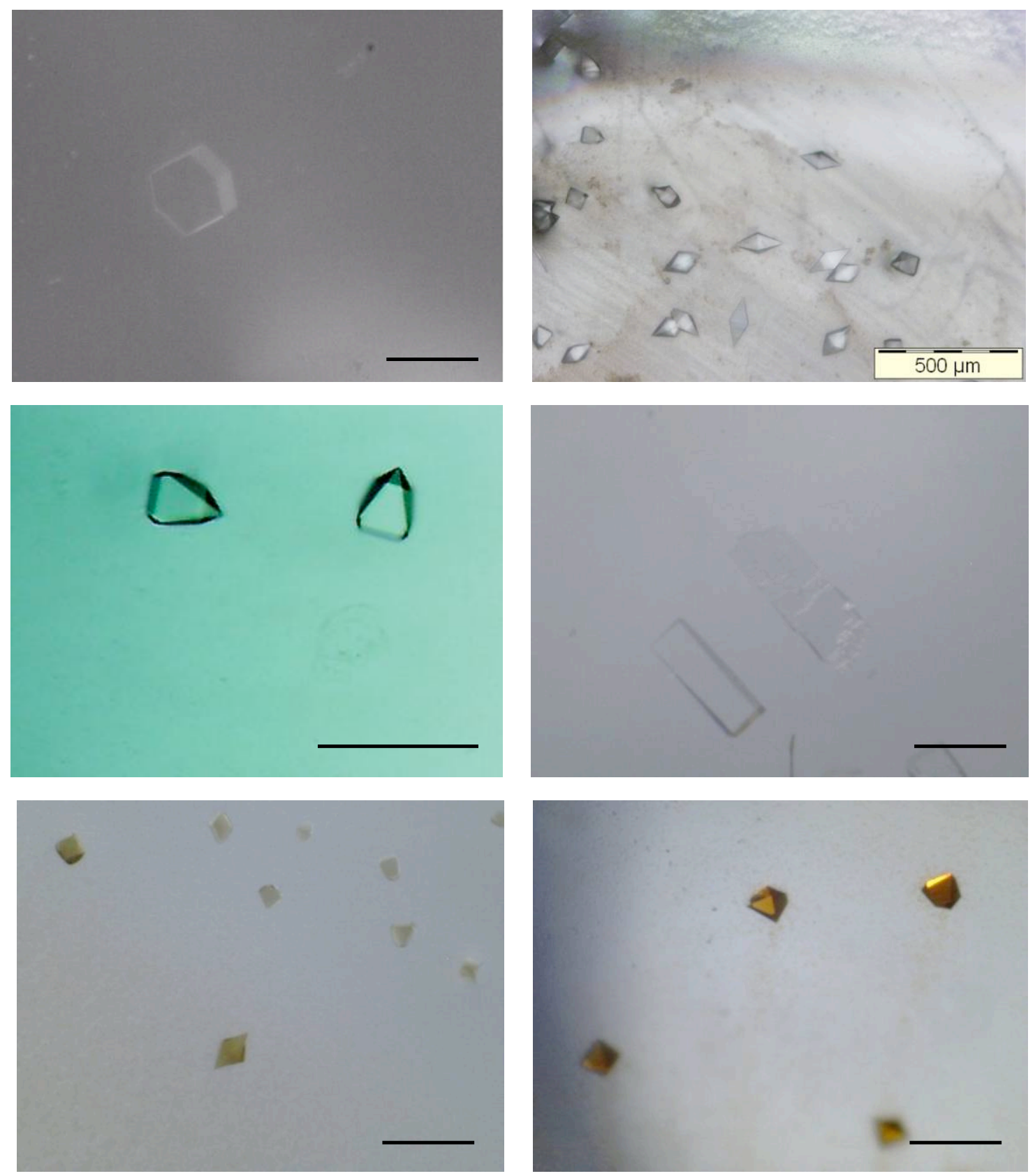

Figure 3 Crystallization of proteins on mesoporous glass surface (a) Lysozyme crystals on surface with 3-4 nm pore diameter (b) Thaumatin crystals on surface with 3-4 nm pore diameter (c) Trypsin crystals on surface with pore diameter $3-4 \mathrm{~nm}$ (d) Concanavalin A crystals obtained on surface with pore diameter $10-12 \mathrm{~nm}$ (e) Catalase crystals obtained on surface with pore diameter 10-12nm (f) Ferritin crystals obtained on surface with pore diameter 17-21nm (Scale bar: $200 \mu \mathrm{m}$ ) (Note: Solution remained clear on the rest of the surfaces at same time) 


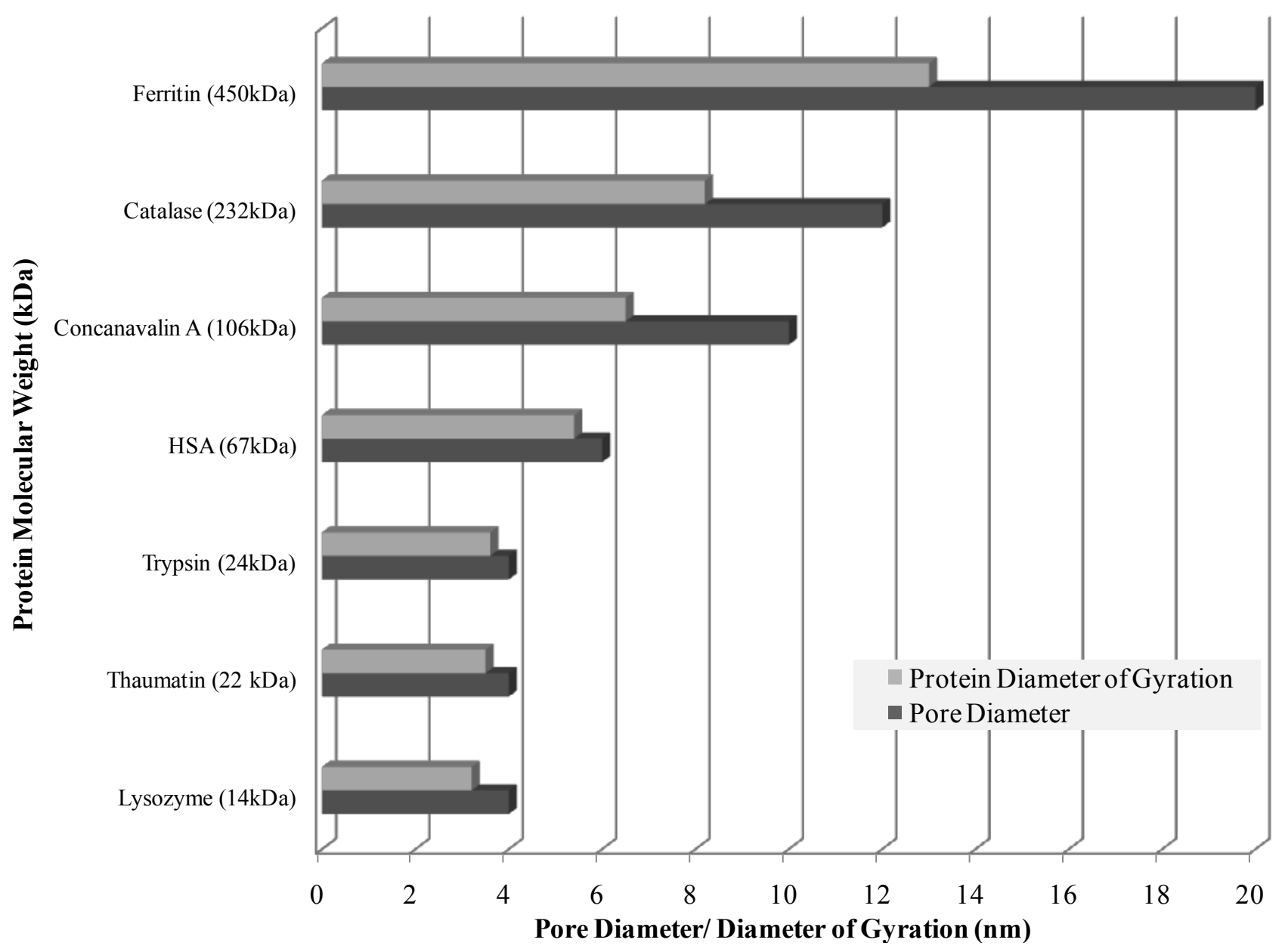

Figure 4 Schematic illustration of behavior of crystallization solution in presence of nucleant surface having narrow pore size distribution. Radius of gyration details is referred from the literature ${ }^{44-48}$. 


\section{Tables:}

Table 1 Physical properties of mesoporous glass prepared with different sacrificial templates.

\begin{tabular}{cccc}
\hline Type of Sample & $\begin{array}{c}\text { Surface area } \\
\left(\mathrm{m}^{2} \mathrm{~g}^{-1}\right)\end{array}$ & $\begin{array}{c}\text { Total pore volume } \\
\left(\mathrm{cm}^{3} \mathrm{~g}^{-1}\right)\end{array}$ & $\begin{array}{c}\text { Average pore diameter } \\
(\mathrm{nm})\end{array}$ \\
\hline Type-I & 658.3 & 0.531 & 4.02 \\
Type-II & 534.1 & 0.584 & 5.69 \\
Type-III & 438.2 & 0.931 & 10.76 \\
Type-IV & 398.5 & 0.982 & 13.12 \\
Type-V & 299.3 & 1.063 & 20.07 \\
\hline
\end{tabular}


Table 2 Details of crystallization results obtained at metastable conditions reported in the literature.

\begin{tabular}{|c|c|c|c|c|c|c|}
\hline $\begin{array}{l}\text { Protein } \\
\text { (Molecular } \\
\text { Weight, kDa) }\end{array}$ & $\begin{array}{c}\text { Control } \\
\text { (Non-Porous) }\end{array}$ & $\begin{array}{l}\text { Pore diameter } \\
\quad(3-4 n m)\end{array}$ & $\begin{array}{l}\text { Pore diameter } \\
\quad(6-8 \mathrm{~nm})\end{array}$ & $\begin{array}{l}\text { Pore diameter } \\
(10-12 \mathrm{~nm})\end{array}$ & $\begin{array}{c}\text { Pore diameter } \\
(13-15 \mathrm{~nm})\end{array}$ & $\begin{array}{l}\text { Pore diameter } \\
\quad(17-21 \mathrm{~nm})\end{array}$ \\
\hline $\begin{array}{l}\text { Lysozyme } \\
\text { (14) }\end{array}$ & $\begin{array}{l}\text { uncontrolled } \\
\text { crystallization }\end{array}$ & $\begin{array}{l}\text { Well faceted } \\
\text { crystals }\end{array}$ & $\begin{array}{c}\text { uncontrolled } \\
\text { crystallization }\end{array}$ & $\begin{array}{l}\text { uncontrolled } \\
\text { crystallization }\end{array}$ & $\begin{array}{l}\text { uncontrolled } \\
\text { crystallization }\end{array}$ & $\begin{array}{l}\text { uncontrolled } \\
\text { crystallization }\end{array}$ \\
\hline $\begin{array}{l}\text { Thaumatin } \\
\text { (22) }\end{array}$ & no crystals & $\begin{array}{l}\text { well faceted } \\
\text { crystals }\end{array}$ & $\begin{array}{l}\text { uncontrolled } \\
\text { crystallization }\end{array}$ & $\begin{array}{l}\text { uncontrolled } \\
\text { crystallization }\end{array}$ & $\begin{array}{l}\text { uncontrolled } \\
\text { crystallization }\end{array}$ & $\begin{array}{l}\text { uncontrolled } \\
\text { crystallization }\end{array}$ \\
\hline Trypsin (24) & no crystals & $\begin{array}{l}\text { well faceted } \\
\text { crystals }\end{array}$ & no crystals & no crystals & no crystals & no crystals \\
\hline $\begin{array}{l}\text { Human } \\
\text { Serum } \\
\text { Albumin (67) }\end{array}$ & no crystals & no crystals & crystals & no crystals & no crystals & no crystals \\
\hline $\begin{array}{l}\text { Concanavalin } \\
\text { A (106) }\end{array}$ & no crystals & $\begin{array}{l}\text { uncontrolled } \\
\text { crystallization }\end{array}$ & no crystals & $\begin{array}{c}\text { well faceted } \\
\text { crystals }\end{array}$ & no crystals & no crystals \\
\hline $\begin{array}{l}\text { Catalase } \\
(232)\end{array}$ & no crystals & no crystals & no crystals & $\begin{array}{l}\text { well faceted } \\
\text { crystals }\end{array}$ & no crystals & no crystals \\
\hline Ferritin (450) & no crystals & no crystals & no crystals & no crystals & $\begin{array}{l}\text { uncontrolled } \\
\text { crystallization }\end{array}$ & $\begin{array}{l}\text { well faceted } \\
\text { crystals }\end{array}$ \\
\hline
\end{tabular}


Table 3 Comparison of protein concentrations reported for crystallization on porous and non-porous hetero-nuclei under similar conditions compared with current mesoporous glasses (Data in column 3 and 4 are the lowest protein concentrations reported for crystals appearance on the relevant nucleant surfaces).

\begin{tabular}{|c|c|c|c|}
\hline $\begin{array}{l}\text { Protein } \\
(\mathrm{MW}, \mathrm{kDa})\end{array}$ & $\begin{array}{c}\text { Protein } \\
\text { Concentration } \\
\text { (mesoporous glass- } \\
\text { present work) }\end{array}$ & $\begin{array}{l}\text { Protein Concentration. } \\
\text { (porous heteronuclei) }\end{array}$ & $\begin{array}{c}\text { Protein Concentration. } \\
\text { (non-porous heteronuclei) }\end{array}$ \\
\hline Lysozyme (14) & $5.0 \mathrm{mg} / \mathrm{ml}$ & $15.0 \mathrm{mg} / \mathrm{ml}^{16}$ & $5.0 \mathrm{mg} / \mathrm{ml}^{7}$ \\
\hline Thaumatin (22) & $2.0 \mathrm{mg} / \mathrm{ml}$ & $16.0 \mathrm{mg} / \mathrm{ml}^{16}$ & $2.0 \mathrm{mg} / \mathrm{ml}^{* 7}$ \\
\hline Trypsin (24) & $11.5 \mathrm{mg} / \mathrm{ml}$ & $12.0 \mathrm{mg} / \mathrm{ml}^{16}$ & $\begin{array}{c}\text { No Comparable data } \\
\text { available** }\end{array}$ \\
\hline $\begin{array}{l}\text { Human Serum } \\
\text { Albumin (67) }\end{array}$ & $75.0 \mathrm{mg} / \mathrm{ml}$ & No data available & $255.0 \mathrm{mg} / \mathrm{ml}^{11}$ \\
\hline Concanavalin A (106) & $2.0 \mathrm{mg} / \mathrm{ml}$ & No data available & $5.0 \mathrm{mg} / \mathrm{ml}^{* 7}$ \\
\hline Catalase (232) & $6.0 \mathrm{mg} / \mathrm{ml}$ & $11.5 \mathrm{mg} / \mathrm{ml}^{16}$ & $\begin{array}{c}\text { No Comparable data } \\
\text { available** }\end{array}$ \\
\hline Ferritin (450) & $1.0 \mathrm{mg} / \mathrm{ml}$ & No data available & $\begin{array}{c}\text { No Comparable data } \\
\text { available** }\end{array}$ \\
\hline
\end{tabular}

*Crystallization was carried out at higher precipitant concentration as compared to the same used in this study.

** Different salt and buffer conditions were used for crystallization in different literature. No comparable data is available for discussion. 
Table 4 Conditions under which the proteins are crystallized in the presence of mesoporous glasses.

\begin{tabular}{|c|c|c|c|}
\hline Name of Protein & $\begin{array}{l}\text { Buffer Solution } \\
\text { (Solvent water) }\end{array}$ & Precipitant Solution & $\begin{array}{c}\text { Final Protein } C \\
(\mathrm{mg} / \mathrm{ml})\end{array}$ \\
\hline Lysozyme & $\begin{array}{c}20 \mathrm{mM} \text { Acetate } \\
\text { buffer, } \mathrm{pH} 4.8\end{array}$ & $0.5-1 \mathrm{M} \mathrm{NaCl}$ & $5.0-15.0$ \\
\hline Thaumatin & $\begin{array}{c}50 \mathrm{mM} \text { PIPES } \\
\text { pH } 6.8\end{array}$ & $\begin{array}{c}340 \mathrm{mM} \\
\text { Na- K Tartrate }\end{array}$ & $2.0-11.5$ \\
\hline Trypsin & $\begin{array}{c}100 \mathrm{mM} \text { Tris } \\
\mathrm{pH} 8.4\end{array}$ & $\begin{array}{c}30-32 \%(\mathrm{w} / \mathrm{v}) \\
\left(\mathrm{NH}_{4}\right)_{2} \mathrm{SO}_{4}\end{array}$ & $11.5-12.0$ \\
\hline $\begin{array}{l}\text { Human Serum } \\
\text { Albumin }\end{array}$ & $\begin{array}{c}\text { 50mM Mono- } \\
\text { potassium } \\
\text { Phosphate pH } 5.15\end{array}$ & $5 \%(\mathrm{w} / \mathrm{v}) \mathrm{PEG} 4 \mathrm{~K}$ & $75.0-255.0$ \\
\hline Concanavalin A & $\begin{array}{c}10 \mathrm{mM} \text { Tris pH 8.5; } \\
20 \mathrm{mM} \mathrm{CaCl}_{2} \\
20 \mathrm{mM} \mathrm{MnCl}_{2}\end{array}$ & $\begin{array}{c}1 \mathrm{M}\left(\mathrm{NH}_{4}\right)_{2} \mathrm{SO}_{4} \text { in } 20 \\
\text { mm Tris pH } 8.0\end{array}$ & $2.0-17.5$ \\
\hline Catalase & $100 \mathrm{mM}$ Tris $\mathrm{pH} 8.4$ & $\begin{array}{c}5 \%(\mathrm{w} / \mathrm{v}) \text { PEG 4K; } \\
5 \%(\mathrm{v} / \mathrm{v}) \text { 2-Methyl-1,3 } \\
\text { Propanediol (MPD) }\end{array}$ & $6.0-11.5$ \\
\hline Ferritin & $\begin{array}{c}200 \text { mM Acetate } \\
\text { buffer, pH } 5.0\end{array}$ & $1.6 \% \mathrm{CdSO}_{4}$ & $1.0-2.8$ \\
\hline
\end{tabular}




\section{For Table of Contents Use Only}

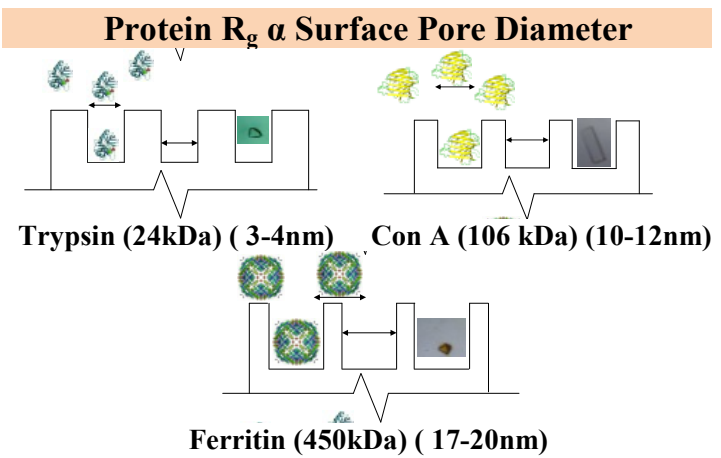

Synopsis: Surface selective crystallization of proteins on engineered nanoporous surfaces with narrow pore size distribution is reported here for the first time. Using engineered nanonucleants, crystallization was observed to be faster and at lower protein concentration. Systematic approach for controlling heterogeneous nucleation of proteins based on a relationship between protein radius of gyration and specific nucleant pore dimensions is proposed. 